\title{
PALEORADIOLÓGIA: NON-INVAZÍV MÓDSZERTANI LEHETŐSÉG A TÖRTÉNETI ANTROPOLÓGIÁBAN
}

\author{
Kristóf Lilla Alida \\ Szegedi Tudományegyetem, Embertani Tanszék, Szeged \\ Témavezetők: Dr. Pálfi György és Dr. Fornet Béla
}

Kristóf L. A.: Paleoradiology: non-invasive methodological possibilities in historical anthropology. The research results confirmed that paleoradiology is a useful examination approach in bioarcheology and historical anthropology, especially in mummy studies. The noninvasive technology facilitates insight into the remains of the body and the bone structure. Next to anthropological age estimation and paleopathological diagnostics, it is also possible to take measurements of bones to tenth of millimetre accuracy, providing bases for development of new anthropometrical techniques. CT data provide basis for virtual 3D reconstruction and printing of any skeletal element or mummified body part, which is of crucial importance in case of skulls and facial reconstructions. The paleoradiological investigations in the case studies of the dissertation yielded several new results with importance not only in physical anthropology but also in historical fields. Replicability of the results may refine hypotheses concerning the life of historical personalities and fate of their dead bodies. The case of Archbishop Pál Széchényi proves that embalming was an established practice in the Baroque era in 11 cases of funerals of high-ranking priests and noblemen. Embalming being involved in medieval royal mortuary practices may be very likely on the basis of research results concerning the Holy Right Hand, but it may also be proposed in case of St. László's skull relic. Paleoradiological examinations of the relics of two early Christian martyrs provided novel anthropological knowledge and important cultural and historical data. Paleoradiological results of the last century in Hungary and especially research in the last decades drew attention to the strong need for a national paleoradiological centre or platform serving anthropological, paleopathological, archeological and historical research projects that could dramatically increase the efficiency and productivity of these interdisciplinary research initiatives.

Keywords: Paleoradiology; Bioarcheology; Non-invasive methodology.

\section{Bevezetés}

A történeti embertani és paleopatológiai vizsgálatok elsődleges forrásai az emberi maradványok (Chhem és Borthwell 2008). Ezen szakterületek számára a különböző módon fennmaradt csontvázak és mumifikálódott/mumifikált tetemek vagy testrészek szolgáltatják a legtöbb információt a régmúlt korok emberéről, betegségeiről, kórokozóiról, táplálkozási és egyéb szokásairól (Pálfi és mtsai 1999, Józsa 1996). A paleoradiológiai vizsgálatok lehetőséget adnak arra, hogy a testbe, a csontszerkezetbe lássunk anélkül, hogy a leleten bármiféle roncsolást okoznánk. A csontok belső szerkezeti változásainak radiológiai értékelése a történeti antropológiában elsősorban az elhalálozási életkor becslésére, vagy a csontok fejlődésének tanulmányozására használható, míg a kóros elváltozásokkal foglalkozó paleopatológiában fontos differenciáldiagnosztikai szerepe van (Ortner és Putschar 1981). Dolgozatomban a paleoradiológiai metodikák rendszerezése, pontosítása mellett azok gyakorlati 
alkalmazása is célkitüzésem volt. Kutatásaim során számos emberi csontváz, illetve mumifikálódott/mumifikált maradvány vizsgálatát végeztem el.

Embertani kutatásaimban az interdiszciplináris szemléletmódra törekedtem: doktori értekezésem a történeti antropológiára épül, de felhasznál számos egyéb orvosi, társadalomtudományi és bölcseleti területről származó információt és metodikát is. A humán maradvány mint biodokumentum jelenik meg a történeti embertanban; az alkalmazott paleoradiológiai módszertani eljárás ugyanakkor átfogó vizsgálati lehetőséget biztosít a leletek strukturális feltérképezéséhez, adatok rögzítéséhez, értékeléséhez és azok ellenőrzéséhez.

\section{Célkitűzések és alkalmazott módszerek}

Doktori kutatásaim célkitüzéseit a következők szerint foglalhatom össze:

- A történeti antropológiában és paleopatológiában alkalmazható paleoradiológiai módszerek áttekintése, a módszertani lehetőségek pontosítása, a felvételtechnika tesztelése, javaslattétel későbbi vizsgálatokhoz.

- Életkorbecslési és diagnosztikai megoldások kidolgozása, pontosítása.

- Humán csontanyagok és mumifikálódott/mumifikált maradványok tanulmányozása radiológiai módszerekkel.

- Esettanulmányok: ismert történelmi személyek, ereklyék paleoradiológiai és interdiszciplináris kutatása.

Paleoradiológiai kutatómunkám során a következő radiológiai eszközöket, módszereket tudtam/tudtuk alkalmazni: hagyományos röntgen, computer tomográfia (CT), digitális volumentomográfia (DVT) és nano CT.

A paleoradiológiai vizsgálatokkal párhuzamosan az egyes leletek történeti hátterét, olykor magának az egyénnek az életútját is fel tudtam dolgozni, történettudományi információk felhasználásával. A különböző módszerekkel elért eredményeket szintetizálva, esettanulmányaim során kísérletet tettem az egyén biológiai antropológiai és eltemetési viszonyainak, élettörténetének, illetve rajta keresztül az adott korszak történetének pontosabb megismerésére.

\section{Vizsgálati eredmények}

Eredményeim első csoportja a paleoradiológiai technikák metodikai teszteléséhez kapcsolható. Doktori munkám egyik célja a paleoradiológiában alkalmazható módszertan tesztelése, rendszerezése és ismertetése volt. A több száz egyén csontmaradványainak hagyományos röntgenvizsgálatával nyert fontosabb felvételtechnikai megfigyeléseim lehetővé tették, hogy pontosabb és értékelhetőbb típusfelvételeket dolgozhassak ki, amelyek alapján megfogalmaztam metodikai javaslataimat. A kidolgozott beállításokat és felvételtechnikai értékeket $(\mathrm{kV}, \mathrm{mAs})$ folyamatosan teszteltem, az eredményeket összegeztem és táblázatokba rendezve bemutattam. A múmiavizsgálatoknál is mind a hagyományos röntgen, mind a CT tekintetében használható protokolljavaslatot sikerült kidolgozni, szintén táblázatos formában bemutatva.

Doktori kutatási eredményeim második csoportja az elsajátított paleoradiológiai ismeretek gyakorlati alkalmazása volt, történeti kori emberi maradványok komplex antropológiai és radiológiai vizsgálatai során. A kutatásokba ismert történelmi személyek maradványai, illetve szent ereklyék kerültek bevonásra, így a rendelkezésre álló egyéb 
ismeretek (pl. történelmi, kultúrtörténeti, életrajzi adatok) birtokában sok esetben kibővített interdiszciplináris projekteket hajthattunk végre.

Széchényi Pál Nagycenken található múmiájának paleoradiológiai és paleopatológiai vizsgálatát 2007-ben végeztük el az általam koordinált kutatócsoporttal. Elsődleges célunk az volt, hogy megtudjuk, természetes vagy mesterséges múmiáról van-e szó, valamint igaz-e az a vélekedés, hogy a kalocsai érsek arzénmérgezés következtében halálozott el 1710-ben, illetve milyen kóros elváltozások diagnosztizálhatók a leleten. A vizsgálatokat non-invazív technikai eszközökkel: multislice CT-vel és hagyományos röntgennel végeztük el, valamint energiadiszperzív röntgenspektrometriai (EDX) vizsgálatra és röntgenfluoreszcens elemanalízisre (XRF) is sor került (Kristóf és mtsai 2010). A vizsgálat eredményei alapján megállapítható, hogy Széchényi Pál testét mesterségesen mumifikálták: a medencéröl készült CT felvételeken látható a testüreg kitöltésére használt töltőanyag. A gerinc több szakaszán a csigolyák, illetve a vállöv egyes csontjai az anatómiai helyzetükböl kimozdulva találhatók, amit a többszöri sírbolygatásnak lehet betudni. A gerincen a hosszanti szalagok elörehaladott elcsontosodása figyelhető meg, ami krónikus csontrendszeri betegség, DISH (diffúz idiopátiás szkeletális hiperosztózis) radiológiai jele (Kristóf és mtsai 2012). A koponya CT vizsgálata $1 \mathrm{~mm}$-töl vékonyabb szeletvastagságban történt, így a felvételek alapján nyomtatott koponyamásolatok megfelelő pontosságúak és részletgazdagságúak voltak az antropológiai vizsgálatokhoz (Molnár és mtsai 2012), valamint a későbbi grafikus arcrekonstrukcióhoz (König 2012).

A paleopatológiai kutatás kiderítette, hogy Széchényi Pál érsek halálát nem arzénmérgezés, hanem feltehetően szív- és érrendszeri megbetegedés okozta. Mind az endoszkópos vizsgálat, mind a CT-felvételek elemzése igazolta, hogy a belső szervek eltávolítása nem a hasfal ventrális oldalán át, hanem a múmia bal oldalán található hosszanti, a hónalj vonalától egészen a medencéig érő nyíláson keresztül történt. Széchényi Pál testén végzett kutatásaink bizonyítják, hogy ha ideiglenes célzattal is, de tartósították egyes elhunyt föméltóságok maradványait. Ennek fö oka az volt, hogy hosszú időt igényelt a reprezentatív temetés megszervezése - Széchényi Pál halála és temetése között például egy hónap telt el, és meg kellett őrizni a test viszonylagos épségét a halálozástól a gyászszertartásig (Istók és mtsai 2015).

A dolgozatomban bemutatott következő esettanulmány a Szent Jobb korábbi vizsgálatainak összehasonlító elemzése volt. Szent István király jobb kezét eddig háromszor lehetett tudományos kutatások alá vonni. Először 1951-ben Bochkor Ádám orvosszakértő vizsgálhatta, látható penészesedés miatt (Bochkor 1960). 1988-ban Szentágothai János és Nemeskéri János vezetésével négy kutató készíthetett vizsgálatokat, majd 1999-ben Réthelyi Miklóst és Patonay Lajost kérték fel a Szent Jobb orvosi-antropológiai tanulmányozására (Réthelyi 2000). Erdő Péter bíboros, esztergomi érsek, valamint Réthelyi professzor és Patonay főorvos engedélyével elemezhettem az 1988-as és 1999-es kutatások anyagait.

Megállapítottam, hogy a különböző időszakokban és különböző kutatók által készített vizsgálatok eredményei között több helyen eltérések figyelhetők meg, és a következtetések nincsenek mindig összhangban egymással: nincs például egységes konszenzus a mumifikálásra vagy mumifikálódásra vonatkozóan. Szembetünő különbségeket mutatnak az 1988-as és az 1999-es oszteometriai eredmények. Az 1999-es adatok ellenőrizhetőségét és nagyobb pontosságát a Szent Jobb esetében akkor első ízben alkalmazott paleoradiológiai vizsgálatok szolgáltatták. Ez utóbbiak jelezték azt is, hogy 
arthrosisra, osteoporosisra utaló jel nem mutatható ki, és egyéb paleopatológiai elváltozást sem lehet megfigyelni a csontokon.

A Szent Jobb kutatási jegyzőkönyveinek áttanulmányozása alapján, a mumifikálás vagy mumifikálódás kérdését illetően a halált követő balzsamozás valószínüsíthető, amely feltehetően nem csak a felső végtagot érintette, hanem eredetileg az egész holttestet.

Kutatásaim fontos esettanulmánya volt a győri Bazilika Héderváry-kápolnájában őrzött Szent László-herma, illetve szent királyunk koponyaereklyéjének általam szervezett komplex vizsgálata. Doktori kutatásaimhoz elsődlegesen a koponya antropológiai és paleoradiológiai vizsgálatai kapcsolódnak.

Szent László király jó megtartási állapotú, mandibula-hiányos koponyája rendkívül férfias (hipermaszkulin) antropológiai jegyekkel bír. A koponya neme, elhalálozási életkora, számos jellegzetessége és a megfigyelt tafonómiai nyomok igazolták annak eredetiségét. A paleoradiológiai vizsgálatok föként postmortem csonthiányt mutattak a koponyaereklye különböző részein, például: a jobb sutura squamosa mentén az os frontalét és temporalét is érintő post mortem darabos töréseket sikerült kimutatni. Az os occipitale bal oldali basalis részén, a foramen magnum hátsó szélén müvi beavatkozásra utaló, szintén halál utáni csonteltávolítás figyelhető meg. A röntgen és CT-felvételek segítettek a királyi ereklye fogazati státuszának meghatározásában. A paleoradiológiai vizsgálatok során a canalis caroticusban felfedezett lemezszerü, illetve apró göbös alakú, mész denzitású képletek érelmeszesedésre, az arteria carotis interna sclerosisára utalhatnak. További érdekesség Szent László koponya CT-felvételén a bal arcüregben látható meszet, vagy fémet tartalmazó gombafonal massza maradványa. Pre- vagy postmortem keletkezése jelenlegi ismereteink szerint még nem dönthető el.

Az utolsó esettanulmányban Szent Augusztusz és Szent Krisztina ókeresztény vértanúk ereklyéinek paleoradiológiai és antropológiai vizsgálatain keresztül tanulmányozhattuk a barokk kori preparálási szokásokat.

2012-ben a két maradvány állapotfelmérése történt meg, paleoradiológiai módszerekkel (Kristóf és mtsai 2015). Két évvel később, a restaurátori munkálatok kezdetével lehetőség adódott az ereklyék antropológiai vizsgálataira is. Az antropológiaianatómiai kutatómunkát kiegészítettük újabb radiológiai megfigyelésekkel, felvételekkel. $\mathrm{Az}$ antropológiai kutatás igazolta a korábbi paleoradiológiai vizsgálatok vélelmezhető eredményét, amely szerint a csontvázakat preparálták. Igazoltuk, hogy a testeket több, mint három ember maradványaiból rakták össze. Szent Augusztusz csontvázában a bal radius helyett egy állati eredetű csontot találtunk. Az ereklyék preparálásánál gyakori tévesztésnek bizonyult az anatómiai helyzettől eltérő képletek összeillesztése, valamint az oldaliság felcserélése. Főként a kéz és a láb csontjait helyettesítették mesterséges kitöltésekkel. Az ujjperceket imitáló papírtekercsek mészszerü anyaggal történő bevonása megtévesztő képet adott a röntgenfelvételeken, poroticus csont hatását keltette.

Az ereklyék természettudományos vizsgálatánál és restaurátori munkálatainál nélkülözhetetlen, hogy a szakterületek képviselöi közösen végezzék a kutatómunkát. Esettanulmányunk során sikerült non-invazív módon tanulmányoznunk és értékelnünk a két ókeresztény vértanú ereklyéit, és azokról számos új információt szolgáltatnunk több érintett tudományterület számára. 


\section{Következtetések}

Kutatási eredményeim megerősítették, hogy a paleoradiológia a történeti antropológiában, és különösen a múmiakutatások területén nagyon hasznos vizsgálati módszer: fontos adatokkal gyarapítja a korábban élt népességekkel, vagy azok egyes képviselőinek életével kapcsolatos ismereteinket. A roncsolásmentes eljárásnak köszönhetően testmaradványokba, vagy a csontok szerkezetébe tekinthetünk be. A történeti antropológiai életkorbecslések, vagy a paleopatológiai diagnosztikai elemzések mellett lehetőség van a csontok tizedmilliméter pontosságú mérésére is, segítve ezzel az újabb antropometriai technikák kifejlesztését. A CT-adatokból a modern technika segítségével létrehozható bármely csontvázelem, vagy mumifikálódott/mumifikált testrész 3D rekonstrukciója és pontos nyomtatása is, ami a koponyák esetében az arcrekonstrukció miatt kiemelt jelentőséggel bír.

A bemutatott esettanulmányok paleoradiológai vizsgálatai sok új eredménnyel szolgáltak, amelyek nem csak az antropológia, hanem a történettudományok számára is jelentőséggel bírhatnak. Az eredmények ellenőrizhetősége konkrétabbá teheti a történeti korokban élt emberek halálával és holttestük sorsával kapcsolatos hipotéziseket. Jó példa erre a mumifikálás tárgyköre. Széchényi Pál érsek esete azt bizonyítja, hogy a balzsamozás bevett gyakorlat volt a barokk kori föpapi és föúri temetkezéseknél. A Szent Jobb vizsgálati eredményeiből feltételezhető, míg Szent László ereklyéje esetén felvethető, hogy már a középkorban éltek ezzel a lehetőséggel a királyi temetéseknél. Két ókeresztény vértanú ereklyéinek paleoradiológiai vizsgálata az új biológiai antropológiai ismeretek mellett értékes kulturális és történeti adatokat is szolgáltatott.

Az elmúlt évszázad hazai paleoradiológiai eredményei, és különösen az utóbbi évtizedek kutatásai rávilágítottak arra, hogy az antropológiai, paleopatológiai, régészeti és történettudományi kutatóhelyeinkben komoly szükség mutatkozik egy közös magyarországi helyszínű paleoradiológiai központ, ill. paleoradiológiai platform kialakítására, amely nagyban megnövelné az interdiszciplináris kutatások hatékonyságát, eredményességét.

\section{Felhasznált irodalom}

Bochkor, Á. (1960): A Szent Jobb orvosi szemmel. Vigilia, 25(8): 492-494.

Chhem, R.K., Brothwell, D.R. (2008, Eds): Paleoradiology. Imaging mummies and fossils. Springer Science \& Business Media, Berlin - Heidelberg.

Istók, R., Glasz, T., Kristóf, L.A., Tóth, V., Hargittai, P., Kerényi, T. (2015): Széchényi Pál múmiájának paleopatológiai vizsgálata. Adalékok a mumifikálás gyakorlatához a barokk kori Magyarországon. In: Kristóf, L.A., Tóth, V. (Szerk.) Széchényi Pál érsek emlékezete. Adalékok az életúthoz és a nagycenki múmia vizsgálatának eredményei. Második kiadás. Győr. 158-165.

Józsa, L. (1996): A Honfoglalás és Árpád-kori magyarság egészsége és betegségei. Gondolat, Budapest.

Kristóf, L.A., Kovács, M., Baksa, G., Bereczki, Zs., Szatmári, F., Patonay, L., Pálfi, Gy., Pohárnok, L. (2015): Condition assessment of two early Christian martyrs', St. Chrisine's and St. Augustine's relics with paleoradiological methods in Hungary. Journal of Cultural Heritage, 16: 249-253. DOI: 10.1016/j.culher.2014.04.001

Kristóf, L.A., Kovács, M., Tóth, G., Pohárnok, L. (2012): Széchényi Pál múmiájának paleoradiológiai vizsgálata. In: Kristóf, L.A., Tóth, V. (Szerk.) Széchényi Pál érsek emlékezete. Adalékok az életúthoz és a nagycenki múmia vizsgálatának eredményei. Györ. 116-125. 
Kristóf, L.A., Pohárnok, L., Kerényi, T., Tóth, V., Istók, R., Tóth, G., Hargittai, P., Fornet, B., Pálfi, Gy. (2010): Paleoradiológia és múmiakutatás. A nagycenki múmia interdiszciplináris vizsgálata és 3D koponyamásolatának nyomtatása CT-adatok alapján. Magyar Radiológia Online, 1(4): 6-16.

Kőnig, F. (2012): Gondolatok Széchényi Pál grafikus arcrekonstrukciójával kapcsolatban. In: Kristóf, L.A, Tóth, V. (Szerk.) Széchényi Pál érsek emlékezete. Adalékok az életúthoz és a nagycenki múmia vizsgálatának eredményei. Györ. 150-153.

Molnár, E., Falk, Gy., Pálfi, Gy., Kristóf, L.A. (2012): Antropológiai vizsgálat Széchényi Pál háromdimenziós, nyomtatott koponyamásolatain. In: Kristóf, L.A., Tóth, V. (Szerk.) Széchényi Pál érsek emlékezete. Adalékok az életúthoz és a nagycenki múmia vizsgálatának eredményei. Györ. 142-149.

Ortner, D.J., Putschar, W.G.J. (1981): Identification of pathological conditions in human skeletal remains. Washington.

Pálfi Gy., Dutour O., Deák J.,Hutás, I. (1999, Eds): Tuberculosis: past and present. Golden Book Publisher - Tuberculosis Foundation, Szeged - Budapest.

Réthelyi, M. (2000): Szent Jobb, anatómus szemmel. Medikus, 9(3): 24-25.

\section{A doktori értekezéshez kapcsolódó, referált, impakt faktorral rendelkezó folyóiratokban megjelent tanulmányok}

Coqueugniot, H., Dutailly, B., Desbarats, P., Boulestin, B., Pap, I., Szikossy, I., Baker, O., Montandon, M., Panuel, M., Karlinger, K., Kovács, B., Kristóf, L.A., Pálfi, Gy., Dutour, O. (2015): Three-dimensional imaging of past skeletal TB: from lesion to process. Tuberculosis, 95: S73-S79. DOI: 10.1016/j.tube.2015.02.004

Kristóf, L.A., Kovács, M., Baksa, G., Bereczki, Zs., Patonay, L., Szatmári, F., Pálfi, Gy., Pohárnok, L. (2015): Condition assessment of two early Christian martyrs', St. Christine's and St. Augustine's relics with paleoradiological methods in Hungary. Journal of Cultural Heritage, 16: 249-253. DOI: 10.1016/j.culher.2014.04.001

Pálfi, Gy., Maixner, F., Maczel, M., Molnár, E., Pósa, A., Kristóf, L.A., Marcsik, A., Balázs, J., Masson, M., Paja, L., Palkó, A., Szentgyörgyi, R., Nerlich, A., Zink, A., Dutour, O. (2015): Unusual spinal tuberculosis in an Avar Age skeleton: a morphological and biomolecular study. Tuberculosis, 95: S29-S34. DOI: 1016/j.tube.2015.02.033

\section{A doktori értekezéshez kapcsolódó további publikációk}

Bernert, Zs., Szikossy, I., Pap, I., Kristóf, L.A., Barta, M., Pálfi, Gy. (2001): Prévalence de fractures dans deus séries anthropologiques hongroises. In: Bérato, J. (Ed.) Centre Archéologique du Var 2001. Toulon. 49-51.

Évinger, S., Bernert, Zs., Józsa, L., Kristóf, L.A. (2003): Two cases of joint disease from the Avar Age, Hungary. Anthropologie (Brno), 41(1-2): 79-85.

Fóthi, E., Pap, I., Kristóf, L.A., Barta, M., Maczel, M., Pálfi, Gy. (2001): A propos d’un nouveau cas paléopathologique de lepre en Hongrie. In: Bérato, J. (Ed.) Centre Archéologique du Var 2001. Toulon. 52-54.

Istók, R., Glasz, T., Kristóf, L.A., Tóth, V., Hargittai, P., Kerényi, T. (2015): Széchényi Pál múmiájának paleopatológiai vizsgálata. Adalékok a mumifikálás gyakorlatához a barokk kori Magyarországon. In: Kristóf, L.A., Tóth, V. (Szerk.) Széchényi Pál érsek emlékezete. Adalékok az életúthoz és a nagycenki múmia vizsgálatának eredményei. Második kiadás. Győr. 158-165.

Kristóf, L.A. (2003): Hagyományos röntgenvizsgálatok a történeti antropológiában. In Penksza, K., Korsós, Z., Pap, I. (Szerk.) III. Kárpát-medencei Biológiai Szimpózium tanulmányai. 305-308.

Kristóf, L.A. (2012): Testek a múltból. Három 18. századi apáca múmiájának vizsgálata, In: Kristóf, L.A., Tóth, V. (Szerk.): Széchényi Pál érsek emlékezete. Adalékok az életúthoz és a nagycenki múmia vizsgálatának eredményei, Győr. 154-169. 
Kristóf, L.A., Barta, M.H., Petrik, A., Pap, I., Pálfi, Gy., Fornet, B., Forrai, G. (2004): „Belelátni a múltba”. Módszertani lehetőségek a paleoradiológiában. Magyar Radiológia, 78(1): 24-31.

Kristóf, L.A., Kovács, M., Baksa, G., Patonay, L., Szatmári, F., Pálfi, Gy., Pohárnok, L. (2014): Mosonmagyaróváron található két ókeresztény vértanú szent maradványának paleoradiológiai vizsgálata. Magyar $\quad$ Radiológia, $\quad$ 5(8): http://www.radiologia.hu/szakma/mro/cikk/mosonmagyarovaron_talalhato_ket_okereszteny_ve rtanu_szent_maradvanyainak_paleoradiologiai_vizsgalata.html

Kristóf, L.A., Kovács, M., Tóth, G., Pohárnok, L. (2012): Széchényi Pál múmiájának paleoradiológiai vizsgálata. In: Kristóf, L.A., Tóth, V. (Szerk.): Széchényi Pál érsek emlékezete. Adalékok az életúthoz és a nagycenki múmia vizsgálatának eredményei, Györ. 116-125.

Kristóf, L.A., Pohárnok, L., Kerényi, T., Tóth, V., Istók, R., Tóth, G., Hargittai, P., Fornet, B., Pálfi, Gy. (2010): Paleoradiológia és múmiakutatás. A nagycenki múmia interdiszciplináris vizsgálata és 3D koponyamásolatának nyomtatása CT-adatok alapján. Magyar Radiológia Online, 1(4): 6-16. http://www.radiologia.hu/uploads/doc/3030 MRO 201004 02.pdf

Kristóf, L.A., Riedl, E., Laki, A., Pap, I., Barta, M.H., Polányi, A., Pálfi, Gy., Tóth, E., Szikossy, I., Kustár, Á., Forrai, G. (2008): Radiology in the historic anthropology. In: Atoche Pena, P., Rodrigez Martin, C., Ramirez Rodriguez, Á. (Ed.) Mummies and Science. World Mummies Research. Proceedings of VI World Congress on Mummy Studies, Santa Cruz. 453-461.

Kristóf, L.A., Tóth, G., Riedl, E., Végvári, Zs., Pohárnok, L., Kustár, Á. (2008): Mummies and face reconstruction. The skull CT examination and 3D printing of baroness Antonia Tauber's and the archbishop of Kalocsa, Pál Széchényi’s mummies. In: Borbás, L. (Ed.) Proceedings of the Third Hungarian Conference on Biomechanics... Budapest. 133-138.

Kristóf, L.A., Tóth, V. (Szerk., 2015): Széchényi Pál érsek emlékezete. Adalékok az életúthoz és a nagycenki múmia vizsgálatának eredményei. Második, bővített kiadás, Győr.

Kustár, Á., Pap, I., Végvári, Zs., Kristóf, L.A., Pálfi, Gy., Karlinger, K., Kovács, B., Szikossy, I. (2011): Use of 3D virtual reconstruction for pathological investigation and facial reconstruction of an 18th century mummified nun from Hungary. In: Gill-Frerking, H., Rosendahl, W., Zink, A. (Eds) Yearbook of Mummy Studies 1, München. 83-93.

Molnár, E., Falk, Gy., Pálfi, Gy., Kristóf, L.A. (2012): Antropológiai vizsgálat Széchényi Pál háromdimenziós, nyomtatott koponyamásolatain. In: Kristóf, L.A., Tóth, V. (Szerk.) Széchényi Pál érsek emlékezete. Adalékok az életúthoz és a nagycenki múmia vizsgálatának eredményei. Győr. 142-149.

Szikossy, I., Kustár, Á., Guba, Zs., Kristóf, L.A., Pap, I. (2010): Naturally mummified corpses from the Dominican Church in Vác, Hungary. In: Wieczorek, A., Rosendahl, W. (Szerk.) Mummies of the world. Munich-Berlin-London-New York. 160-171.

Levelezési cím: $\quad$ Kristóf Lilla Alida

Mailing address: Szegedi Tudományegyetem, Természettudományi és Informatikai Kar Embertani Tanszék

Közép fasor 52.

H-6726 Szeged

Hungary

kristof.lilla@hotmail.hu 
